\title{
PENGARUH MODEL PEMBELAJARAN INKUIRI TERBIMBING TERHADAP PENGUASAAN KONSEP DAN KETERAMPILAN PROSES SAINS FISIKA PESERTA DIDIK KELAS XI MAN 2 MATARAM TAHUN PELAJARAN 2017/2018
}

\author{
*Putri Kurnia Suwandari, Muhammad Taufik, Satutik Rahayu \\ Program Studi Pendidikan Fisika, Universitas Mataram \\ *Email: putrisuwandari8@gmail.com
}

\begin{abstract}
This research is aimed to examine the effect of guided inquiry learning model toward physics students' concept mastery and science process skills at class XI of MAN 2 Mataram in academic year 2017/2018. This is experiment research with posttest-only control group design. The Population of this research is all students of class XI MIA MAN 2 Mataram. The sampling technique used is purposive and cluster random sampling, which is the students of class XI MIA 5 as experiment and XI MIA 4 as control group. The experiment group was treated with guided inquiry learning model while the control group was treated with conventional learning. Technique of collectig data of the mastery concept using essay test 8 question, the skills of science process using non-test instruments in the form of observation sheets. The hypothesis was tested using manova based SPSS 16.0. The result of manova test showed that there was an effect of guided inquiry learning model toward mastery of concept and skill of science process.
\end{abstract}

Keywords: guided inquiry, mastery of concept, science process skills

\section{PENDAHULUAN}

Ilmu Pengetahuan Alam (IPA) merupakan kumpulan pengetahuan yang berupa fakta, konsep, prinsip serta proses penemuan. IPA berkaitan dengan cara mencari tahu tentang fenomena alam secara sistematis. Pada hakikatnya sains mencakup proses, produk, dan sikap. Sains sebagai proses, lebih mengutamakan pada proses bagaimana cara memperoleh ilmu pengetahuan alam. Sains sebagai produk, lebih menekankan hasil yang diperoleh dalam kegiatan sains itu, baik konsep, maupun persamaan-persamaan. Sains sebagai sikap lebih menekankan pada upaya membekali, melatih, atau menanamkan nilai-nilai positif dalam diri peserta didik (Gunawan, 2015).

Fisika merupakan salah satu cabang IPA yang tidak hanya berupa kumpulan fakta, konsep, prinsip atau proses penemuan saja tetapi juga pengembangan lebih lanjut dalam menerapkannya di dalam kehidupan sehari-hari. Pembelajaran fisika harus diarahkan untuk mencari informasi dan berbuat sehingga dapat membantu peserta didik untuk memperoleh konsep yang lebih mendalam, oleh sebab itu, pembelajaran fisika harus menekankan pada pemberian pengalaman lansung yang berpusat pada peserta didik (Yeritia et al., 2017).

Menurut Doyan \& Sukmantara (2014) menyatakan bahwa konsep merupakan segala sesuatu yang berwujud pengertianpengertian baru yang dapat timbul sebagai hasil pemikiran meliputi definisi, pengertian, ciri khusus, hakikat, inti atau isi dan sebagainya. Penguasaan menurut Kamus Besar Bahasa Indonesia merupakan pemahaman atau kesanggupan untuk menggunakan pengetahuan, kepandaian dan sebagainya. Adapun yang dimaksud penguasaan konsep menurut Silaban (2014), adalah usaha yang dilakukan oleh peserta didik dalam merekam dan mentransfer kembali sejumlah informasi yang didapatkan dari suatu materi pelajaran tertentu.

Siswa yang mengembangkan penguasaan konsep akan lebih cepat 
melakukan hal-hal yang terkait dengan pengetahuan prosedural nantinya dibandingkan dengan peserta didik yang menghafal dan mengingat saja (Nisrina, et. al., 2016). Penguasaan konsep menurut Suranti et al. (2016) sangat penting bagi peserta didik agar mampu berkomunikasi, mengklasifikasikan ide, gagasan atau peristiwa yang dialaminya dalam kehidupan sehari-hari. Hal ini yang membuat peserta didik nantinya juga menjadi terampil dalam kegiatan-kegiatan sainsnya.

Selain penguasaan konsep, tujuan pembelajaran fisika adalah mengembangkan kemampuan berfikir dan bertindak berdasarkan pengetahuan sains yang dimilikinya, atau lebih dikenal dengan keterampilan proses sains. Keterampilan proses sains merupakan keterampilan yang sangat penting untuk mengembangkan sikap ilmiah peserta didik dan keterampilan memecahkan masalah, sehingga dapat membentuk peserta didik yang kreatif, kritis, terbuka, inovatif dan kompetitif dalam persaingan dunia global di masyarakat (Budiyono \& Hartini, 2016). Hikmawati, et al., 2017 menyatakan bahwa beberapa keterampilan proses sains yang harus dimiliki peserta didik yakni kemampuan mengamati, mengklasifikasi, menafsirkan, meramalkan, menerapkan, merencanakan penelitian dan mengkomunikasikan.

Berdasarkan hasil observasi dan wawancara di MAN 2 Mataram, masih dite ukan pembelajaran yang berpusat pada guru sehingga keaktifan peserta didik cenderung rendah. Umumnya peserta didik dituntut untuk lebih banyak menghafal rumus-rumus fisika yang terdapat dalam buku pelajaran. Selain itu, kegiatan praktikum sangat jarang dilakukan. Hal ini dibuktikan dengan laboratorium yang kotor dan alat-alat praktikum hampir tidak layak digunakan. Fakta inilah yang memberikan dampak pada penguasaan konsep dan keterampilan proses sains peserta didik rendah.
Menyikapi permasalahan tersebut, salah satu model pembelajaran yang dapat membantu peserta didik untuk mengembangkan penguasaan konsep dan keterampilan proses sainsnya adalah model inkuiri terbimbing. Inkuiri terbimbing merupakan model yang dapat melatih peserta didik dalam menemukan permasalahan dan menyelesaikannya dibawah bimbingan guru.

Pembelajaran inkuiri terbimbing terdiri dari enam fase yang sangat penting yakni menyajikan pertanyaan atau masalah, membuat hipotesis, merancang percobaan, melakukan percobaan untuk memperoleh informasi, mengumpulkan dan menganalisis data, membuat kesimpulan (Trianto, 2007). Penekanan utama pembelajaran inkuiri terbimbing terletak pada kemampuan peserta didik dalam mencari dan menemukan sendiri jawaban dari permasalahan yang diberikan dengan menggunakan keterampilannya, sedangkan guru berperan sebagai fasilitator dan pembimbing peserta didik selama kegiatan pembelajaran. Dengan demikian, pembelajaran inkuiri ini dirasa dapat membantu peserta didik untuk mengonstruksi konsep fisika yang dipelajari melalui keterampilan prosesnya.

\section{METODE PENELITIAN}

Jenis penelitian ini adalah penelitian eksperimen dengan desain posttest-only control group. Desain penelitiannya dapat dilihat pada Tabel 1 berikut.

Tabel 1. Desain Penelitian

\begin{tabular}{lcc}
\hline Kelompok & Perlakuan & Posttest \\
\hline Eksperimen & $\mathrm{X}$ & $\mathrm{O}_{1}$ \\
Kontrol & $\mathrm{Y}$ & $\mathrm{O}_{2}$ \\
\hline \multicolumn{2}{c}{ (Setyosari, 2013) }
\end{tabular}

Keterangan:

$\mathrm{X}=$ Pembelajaran dengan model inkuiri terbimbing.

$\mathrm{Y}=$ Pembelajaran dengan model direct instruction secara konvensional. 
$\mathrm{O}_{1}=$ Kelas eksperimen diberikan tes akhir.

$\mathrm{O}_{2}=$ Kelas kontrol diberikan tes akhir.

Teknik pengambilan sampel yang pertama dilakukan adalah dengan teknik purposive sampling. Purposive sampling diambil oleh peneliti karena memiliki alasan-alasan khusus. Hal ini dikarenakan adanya kelas unggulan yang peserta didiknya memiliki kemampuan awal yang tidak setara dengan peserta didik kelas lainnya. Teknik pengambilan sampel yang kedua dilakukan dengan teknik cluster random sampling. Teknik kelompok atau rumpun (cluster) digunakan apabila populasi atau sampel yang tersedia adalah berupa unit-unit rumpun dalam populasi (Setyosari, 2013). Dari kedua teknik ini didapatkan kelas XI MIA 5 sebagai kelas eksperimen dan kelas XI MIA 4 sebagai kelas kontrol.

Penelitian ini memiliki 3 jenis variabel yaitu variabel bebas seperti model pembelajaran inkuiri terbimbing, variabel terikat seperti penguasaan konsep dan keterampilan proses sains, variabel kontrol seperti guru yang mengajar, bahan ajar dan instrumen penilaian.

Teknik pengumpulan data dilakukan dengan menggunakan instrumen tes untuk penguasaan konsep dan instrument non tes untuk keterampilan proses sains. Penguasaan konsep menggunakan instrument soal berbentuk uraian sebanyak 10 item yang tersebar pada setiap sub-materi dan setiap komponen kognitif dari $\mathrm{C} 1$ sampai C6. Keterampilan proses sains peserta didik menggunakan instrumen dalam bentuk rubrik penilaian berdasarkan indikator yang akan dicapai. Indikiator yang dimaksud terdiri dari mengamati, mengklasifikasi, menafsirkan pengamatan, meramalkan, merencanakan dan melaksanakan percobaan, menerapkan konsep dan berkomunikasi.

Setelah data dikumpulkan kemudian diolah dengan menguji homogenitas dan normalitannya terlebih dahulu. Tujuannya adalah untuk mengetahui sebaran data serta untuk memilih persamaan yang akan digunakan saat melakukan uji hipotesis.

\section{HASIL DAN PEMBAHASAN}

Penelitian ini bertujuan untuk mengetahui pengaruh penggunaan model pembelajaran inkuiri terbimbing terhadap penguasaan konsep dan keterampilan proses sains fisika peserta didik kelas XI MAN 2 Mataram tahun pelajaran 2017/2018. Kegiatan yang dilakukan dengan memberikan perlakuan berupa penerapan model pembelajaran inkuiri terbimbing yaitu pada kelas XI MIA 5 sebagai kelas eksperimen dan pembelajaran direct instruction pada kelas XI MIA 4 sebagai kelas kontrol.

Setelah kedua kelas diberi perlakuan, peneliti memberikan tes akhir pada kelas eksperimen dan kelas kontrol untuk mengukur pengaruh perlakuan yang telah diberikan. Sebelumnya data diuji homogenitas dan normalitas terlebih dahulu. Untuk tes akhir penguasaan konsep, kelas eksperimen memperoleh nilai rata-rata lebih tinggi dibandingkan kelas kontrol. Nilai keterampilan proses sains yang didapatkan peserta didik selama proses pembelajaran berlangsung diperoleh nilai rata-rata kelas eksperimen lebih tinggi dibandingkan kelas kontrol. Setelah itu dilakukanlah pengujian hipotesis. Dalam melakukan pengujian hipotesis digunakan uji MANOVA dengan berbantuan SPSS 16.0 yang bertujuan untuk mengetahui pengaruh model pembelajaran inkuiri terbimbing terhadap penguasaan konsep dan keterampilan proses sains fisika.

Penguasaan konsep yang diteliti yaitu pada ranah kognitif dari $\mathrm{C} 1$ hingga $\mathrm{C} 6$. Berdasarkan hasil penelitian untuk tes penguasaan konsep, peserta didik pada kelas eksperimen mendapatkan skor rata-rata item soal nomor 1, 2, 4, 5, 6 dan 8 lebih tinggi dibandingkan kelas kontrol. Sedangkan 
untuk item soal nomor 3 dan nomor 7 peserta didik pada kelas eksperimen mendapatkan skor rata-rata lebih rendah dari kelas kontrol. Item soal nomor 3 membahas tentang bagaimana menyelesaikan suatu permasalahan dengan menggunakan persamaan-persamaan modulus elastisitas. Hal ini menunjukkan bahwa peserta didik pada kelas eksperimen kurang mampu mengaplikasikan persamaan-persamaan modulus elastisitas dalam kehidupan seharihari yang dibuktikan dengan hasil tes penguasaan konsep peserta didik item soal nomor 3 pada kelas eksperimen banyak yang tidak menjawab atau mendapatkan skor nol. Sedangkan item soal nomor 7 membahas tentang bagaimana menyelesaikan permasalahan berdasarkan gambar susunan pegas yang disediakan. Berdasarkan perhitungan menunjukkan bahwa sebagian peserta didik kurang mampu menyelesaikan persoalan dengan menganalisis gambar susunan pegas dan sisanya tidak menjawab karena kurangnya waktu yang disediakan untuk menjawab soal.

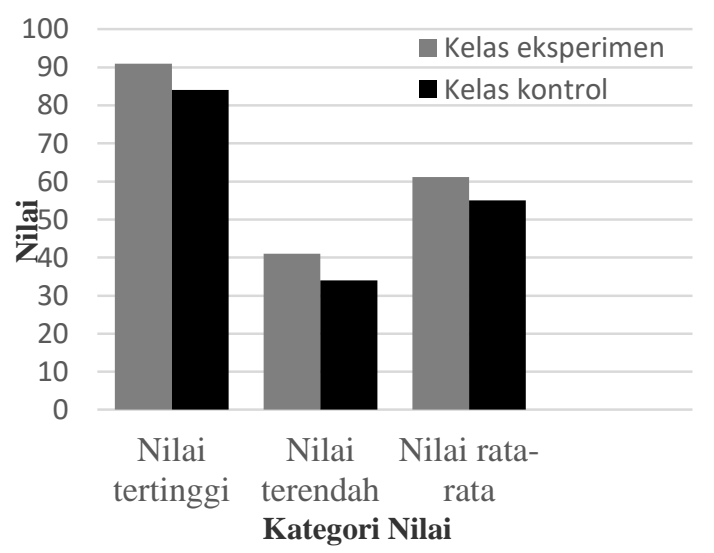

Gambar 1. Hasil Tes Akhir Penguasaan Konsep Peserta Didik

Rendahnya skor item soal nomor 3 dan nomor 7 pada kelas eksperimen disebabkan karena pembelajaran inkuiri dikelas eksperimen pada subbab modulus elastisitas dan susunan pegas kurang efektif dan situasi kelas kurang mendukung. Adapun nilai yang diperoleh masing-masing kelas untuk tes penguasaan konsep dapat dilihat pada Gambar 1.

Gambar 1 menunjukkan bahwa hasil tes akhir penguasaan konsep kelas eksperimen memiliki nilai tertinggi, nilai terendah dan nilai rata-rata lebih tinggi dibandingkan kelas kontrol. Hal ini menunjukkan bahwa ada pengaruh model pembelajaran inkuiri terbimbing terhadap penguasaan fisika peserta didik.

Penerapan pembelajaran inkuiri terbimbing melibatkan peserta didik untuk lebih aktif dalam menyelesaikan suatu permasalahan yang disediakan. Cara yang dilakukan dengan melakukan eksperimen sehingga peserta didik dapat membuktikan sendiri melalui percobaan untuk serta melakukan diskusi untuk menyelesaikan permasalahan yang telah disediakan.

Penerapan model pembelajaran inkuiri terbimbing akan menjadikan pembelajaran lebih bermakna karena peserta didik sendiri yang mengalami langsung sehingga dapat mengkontruksi pengetahuannya sendiri dan apa yang dipelajari tidak hanya berorientasi pada buku teks saja akan tetapi pada kebutuhan dan pengalamannya sehari-hari selama berinteraksi dengan alam sekitarnya sehingga peserta didik dapat memecahkan permasalahan berdasarkan fakta dan pengamatan.

Hasil penelitian yang didapatkan dapat mendukung beberapa penelitian sebelumnya diantaranya penelitian yang dilakukan oleh Sabahiyah, et al (2013) menyatakan bahwa model pembelajaran inkuiri terbimbing berpengaruh terhadap peningkatan penguasaan konsep peserta didik, karena peserta didik yang menemukan sendiri konsep yang dipelajarinya secara langsung melalui kegiatan ilmiah sehingga konsepkonsep tersebut akan lebih mudah dipahami dan akan melekat pada pikiran peserta didik dan sulit untuk dilupakan. Penelitian yang telah dilakukan oleh Yulianci et al. (2017) juga menyatakan bahwa penguasaan konsep 
peserta didik dapat ditingkatkan melalui pembelajaran model inkuiri terbimbing berbantuan multimedia interaktif.

Penelitian ini juga meneliti keterampilan proses sains peserta didik pada saat proses pembelajaran, baik kelas eksperimen maupun kelas kontrol. Instrumen yang digunakan untuk mengukur keterampilan proses sains peserta didik adalah lembar observasi keterampilan proses sains. Data keterampilan proses sains peserta didik ditinjau dari 7 indikator keterampilan yaitu mengamati, mengklasifikasi, menafsirkan pengamatan, meramalkan, merencanakan dan melaksanakan penelitian, menerapkan konsep dan berkomunikasi. Adapun nilai yang diperoleh masing-masing kelas untuk keterampilan proses sains dapat dilihat pada Gambar 2 berikut.

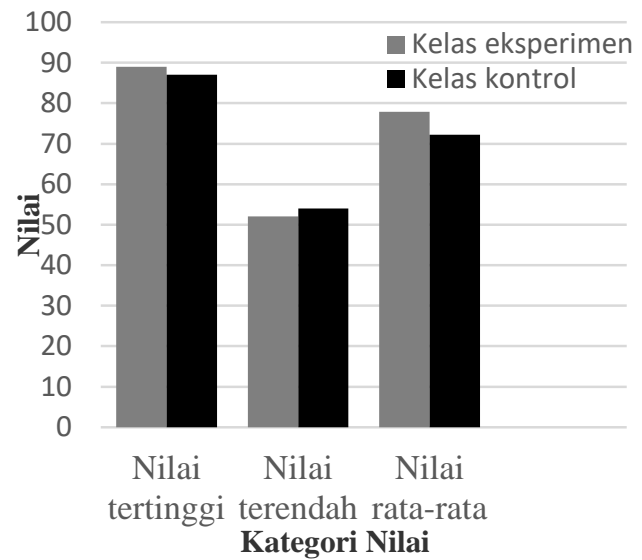

Gambar 2. Hasil Keterampilan Proses Sains Peserta Didik

Gambar 2 menunjukkan bahwa nilai rata-rata keterampilan proses sains peserta didik pada kelas eksperimen lebih tinggi dibandingkan kelas kontrol. Penjelasan setiap indikator keterampilan proses sains yang dikembangkan sebagai berikut:

\section{Keterampilan Mengamati}

Analisis hasil keterampilan mengamati yang diperoleh berdasarkan hasil perhitungan yaitu kelas eksperimen mendapatkan skor rata-rata sebesar 137 dan kelas kontrol mendapatkan skor rata-rata sebesar 122. Hasil ini menunjukkan perbedaan yang signifikan antara kedua kelas, yang diakibatkan karena salah satu tahap pembelajaran inkuiri terbimbing yang digunakan pada kelas eksperimen mendukung indikator mengamati. Tahap yang dimaksud adalah menyajikan pertanyaan atau masalah. Melalui fase ini peserta didik dituntut untuk menganalisis pendapat yang disampaikan dengan cara mengamati permasalahan yang terdapat pada LKPD sehingga peserta didik dapat menemukan permasalahan utama.

\section{Keterampilan Mengklasifikasi}

Keterampilan

mengklasifikasi

merupakan keterampilan mengelompokkan yang dalam penelitian ini peserta didik dituntut agar dapat mengelompokkan permasalahan yang sesuai dengan permasalahan utama pada LKPD. Berdasarkan hasil perhitungan, didapatkan skor rata-rata kelas eksperimen adalah 125 dan skor rata-rata kelas kontrol yaitu 119 . Perbedaan hasil yang didapatkan pada kelas eksperimen dan kelas kontrol disebabkan karena pada kelas eksperimen yang menggunakan pembelajaran inkuiri terbimbing dituntut menemukan permasalahan sesuai LKPD. Permasalahan yang didapatkan tersebut akan memudahkan peserta didik dalam merancang hipotesis.

\section{Keterampilan Menafsirkan \\ Pengamatan}

Keterampilan

menafsirkan pengamatan ialah keterampilan menentukan variabel dan langkah yang tepat untuk solusi terbaik. Berdasarkan hasil perhitungan, didapatkan skor rata-rata kelas eksperimen yaitu 130. Skor rata-rata kelas kontrol yaitu 118. Hasil ini membuktikan bahwa peserta didik yang menggunakan pembelajaran inkuiri terbimbing lebih mudah dalam menafsirkan pengamatan daripada peserta didik dengan pembelajaran langsung.

\section{Keterampilan Meramalkan}

Berdasarkan hasil perhitungan skor rata-rata yang diperoleh kelas eksperimen 
adalah 143, dan kelas kontrol adalah 116. Pada keterampilan ini memperoleh selisih yang cukup besar antara kelas eksperimen dan kelas kontrol. Hal ini disebabkan karena salah satu fase inkuiri terbimbing yang digunakan pada kelas eksperimen mendukung keterampilan meramalkan. Tahap yang dimaksud adalah tahap membuat hipotesis. Tahap ini melatih peserta didik untuk mengembangkan kemampuan berhipotesis yang diberikan pada LKPD. Peserta didik dituntut untuk memberikan hipotesis atas sebuah permasalahan, sedangkan pada kelas kontrol pesera didik hanya melakukan eksperimen sesuai tahapan LKPD.

\section{Keterampilan Merencanakan dan Melaksanakan Percobaan}

Keterampilan ini menuntut peserta didik untuk dapat merangkai alat dan bahan yang akan digunakan selama kegiatan eksperimen. Berdasarkan hasil perhitungan skor rata-rata yang diperoleh kelas eksperimen adalah 159 sedangkan kelas kontrol adalah 139. Skor rata-rata pada keterampilan ini merupakan skor yang paling terbesar diantara skor keterampilan yang lainnya. Hal ini disebabkan karena peserta didik terlibat langsung dalam kegiatan percobaan, sehingga melatih kemampuan eksperimennya. Perbedaan skor yang didapatkan pada kelas eksperimen dan kelas kontrol disebabkan karena pada kelas eksperimen menggunakan LKPD inkuiri terbimbing yang didalamnya terdapat langkah-langkah kerja yang lebih memudahkan peserta didik dalam melakukan percobaan.

\section{Keterampilan Menerapkan Konsep}

Berdasarkan hasil perhitungan skor rata-rata kelas eksperimen yaitu 134 sedangkan skor rata-rata kelas kontrol yaitu 114. Keterampilan menerapkan konsep diamati dari hasil kerja LKPD peserta didik dalam menganalisis data, menafsirkan data dalam grafik serta menjawab pertanyaan- pertanyaan. Skor rata-rata kelas eksperimen lebih tinggi daripada kelas kontrol, karena pada kelas eksperimen peserta didik dalam menerapkan konsep mengacu kepada rumusan masalah sehingga interpretasi data yang dihasilkan lebih terarah.

\section{Keterampilan Berkomunikasi}

Keterampilan berkomunikasi merupakan aspek yang sangat penting untuk menyampaikan ide, fakta, dan konsep. Berdasarkan hasil perhitungan, skor rata-rata kelas eksperimen yaitu 122 sedangkan kelas kontrol 111. Hal ini menunjukan bahwa kelas eksperimen lebih mudah menyampaikan ide, fakta serta konsep yang dimiliki yang di dukung dari penggunaan model pembelajaran inkuiri terbimbing.

Hasil penelitian yang sudah dilakukan menggambarkan keterampilan proses sains peserta didik berbeda. Kelas eksperimen lebih mampu menunjukkan keterampilan proses sains yang dimiliki. Hal ini disebabkan karena masing-masing tahap inkuiri terbimbing membelajarkan peserta didik akan keterampilan proses sains (Wulanningsih et al., 2012).

Hasil ini juga didukung oleh beberapa penelitian sebelumnya diantaranya penelitian yang dilakukan oleh Susilawati et al., (2015) menyatakan bahwa peserta didik yang mendapatkan pembelajaran dengan model inkuiri terbimbing secara keseluruhan memperoleh keterampilan proses sains lebih baik dibandingkan dengan peserta didik yang mendapatkan pembelajaran dengan model pembelajaran konvensional. Serta dalam penelitian lain disebutkan bahwa kelompok yang menggunakan model pembelajaran inkuiri terbimbing lebih baik dari kelompok yang menggunakan model konvensional (Budiyono \& Hartini, 2016).

Pada hipotesis, penelitian ini meneliti pengaruh model pembelajaran inkuiri terbimbing terhadap penguasaan konsep dan keterampilan proses sains fisika peserta didik. Untuk mengukur dua variabel terikat 
sekaligus maka digunakan uji-Manova. Syarat utamanya dalam pengujian ini adalah data homogen. Dalam menguji homogenitas uji manova, digunakan bantuan program aplikasi SPSS 16.

Berdasarkan hasil hitung manual uji manova didapatkan bahwa nilai $F_{\text {hitung }}$ lebih besar dari $F_{\text {tabel }}$ yaitu 3,43>1,67 dengan taraf signifikan sebesar 5\% sehingga $\mathrm{H}_{01}$ dapat ditolak. Artinya bahwa dengan menggunakan model pembelajaran inkuiri terbimbing dapat memberikan pengaruh yang signifikan terhadap penguasaan konsep dan keterampilan proses sains fisika peserta didik.
Selain perhitungan menggunakan persamaan atau secara manual, penelitian ini juga menghitung menggunakan aplikasi SPSS 16 sebagai data pendukung untuk mendapatkan hasil penelitian yang sesuai. Berdasarkan hasil perhitungan menggunakan aplikasi SPSS 16 pada Tabel 2 terlihat bahwa nilai signifikansi untuk model kurang dari 0,050. Dengan kategori pengujian jika nilai sig. $<0,050 \mathrm{H}_{0}$ ditolak, maka terdapat pengaruh model pembelajaran inkuiri terbimbing terhadap penguasaan konsep dan keterampilan proses sains.

Tabel 2. Multivariate Test

\begin{tabular}{|c|c|c|c|c|c|c|c|}
\hline & Effect & Value & $\mathrm{F}$ & $\begin{array}{c}\text { Hypothesis } \\
\text { df }\end{array}$ & $\begin{array}{c}\text { Error } \\
\text { df }\end{array}$ & Sig. & $\begin{array}{l}\text { Partial } \\
\text { Eta } \\
\text { Squared }\end{array}$ \\
\hline \multirow[t]{4}{*}{ Intercept } & Pillai's Trace & .989 & $3.634 \mathrm{E}^{\mathrm{a}}$ & 2.000 & 83.000 & .000 & .989 \\
\hline & Wilks' Lambda & 011 & $3.634 \mathrm{E}^{\mathrm{a}}$ & 2.000 & 83.000 & .000 & .989 \\
\hline & Hotelling's Trace & 87.571 & $3.634 \mathrm{E}^{\mathrm{a}}$ & 2.000 & 83.000 & .000 & .989 \\
\hline & Roy's Largest Root & 87.571 & $3.634 \mathrm{E}^{\mathrm{a}}$ & 2.000 & 83.000 & .000 & .989 \\
\hline \multirow[t]{4}{*}{ Model } & Pillai's Trace & .120 & $5.648^{\mathrm{a}}$ & 2.000 & 83.000 & .005 & .120 \\
\hline & Wilks' Lambda & .880 & $5.648^{\mathrm{a}}$ & 2.000 & 83.000 & .005 & .120 \\
\hline & Hotelling's Trace & .136 & $5.648^{\mathrm{a}}$ & 2.000 & 83.000 & .005 & .120 \\
\hline & Roy's Largest Root & .136 & $5.648^{\mathrm{a}}$ & 2.000 & 83.000 & .005 & .120 \\
\hline
\end{tabular}

Berdasarkan hasil penelitian yang telah dilakukan, terdapat kesamaan hasil dengan penelitian-penelitian sebelumnya salah satunya yaitu penelitian yang dilakukan oleh Hariyadi, et. al., (2016). Hariyadi, et. al. menyimpulkan bahwa penggunaan model pembelajaran inkuiri terbimbing dapat meningkatkan penguasaan konsep dan keterampilan proses sains IPA peserta didik.

\section{PENUTUP}

Berdasarkan hasil dari analisis data yang telah dilakukan maka dapat disimpulkan bahwa terdapat pengaruh penguasaan konsep dan keterampilan proses sains fisika peserta didik antara kelas eksperimen yang diberikan perlakuan berupa penggunaan model pembelajaran inkuiri terbimbing terhadap kelas kontrol yang diberikan perlakuan berupa model pembelajaran direct instruction. Penguasaan konsep dan keterampilan proses sains siswa kelas eksperimen lebih tinggi dari kelas kontrol maka dapat dikatakan bahwa penggunaan model pembelajaran inkuiri terbimbing berpengaruh terhadap penguasaan konsep fisika dan keterampilan proses sains.

Model pembelajaran inkuiri terbimbing dapat diterapkan oleh guru dalam proses pembelajaran, sebagai salah satu alternatif model pembelajaran yang efektif terhadap penguasaan konsep dan keterampilan proses sains peserta didik. Kegiatan pembelajaran harus lebih di 
optimalkan agar mendapatkan hasil yang lebih baik lagi

\section{REFERENSI}

Budiyono, A \& Hartini. 2016. Pengaruh Model Pembelajaran Inkuiri Terbimbing Terhadap Keterampilan Proses Sains Siswa SMA. Jurnal Pemikiran Penelitian Pendidikan dan Sains. 4(2), 141-149.

Doyan, A. \& Sukmantara. I.K.Y. 2014. Pengembangan WEB Intranet Fisika untuk Meningkatkan Penguasaan Konsep dan Kemampuan Pemecahan Masalah Siswa SMK. Jurnal Pendidikan Fisika Indonesia. 10(2), 117-127.

Gunawan. 2015. Model Pembelajaran Sains Berbasis ICT. Mataram: FKIP UNRAM.

Hariyadi, D., Ibrohim \& Rahayu, S. 2016. Pengaruh Model Pembelajaran Inkuiri Terbimbing Berbasis Lingkungan Terhadap Keterampilan Proses dan Penguasaan Konsep IPA Siswa Kelas VII SMP Negeri 4 Kopang Pada Materi Ekosistem. Jurnal Pendidikan: Teori, Penelitian, dan Pengembangan. 1(8), 1567-1574.

Hikmawati, N., Sutrio \& Hikmawati. 2017. Pengaruh Model Pembelajaran Berbasis Masalah dengan Pembekalan Pengetahuan Awal Terhadap Keterampilan Proses Sains Peserta Didik SMA. Jurnal Pendidikan Fisika dan Teknologi. 3(1), 92-100.

Nisrina, N., Gunawan., \& Harjono, A. 2016. Pembelajaran Kooperatif dengan Media Virtual untuk Peningkatan Penguasaan Konsep Fluida Statis Siswa. Jurnal Pendidikan Fisika dan Teknologi. 2(2), 66-72.

Sabahiyah, Marhaeni, A.A.I.N \& Suastra, I.W. 2013. Pengaruh Model Pembelajaran Inkuiri Terbimbing Terhadap Keterampilan Proses Sains dan Penguasaan Konsep IPA Siswa Kelas V Gugus 03 Wanasaba Lombok Timur. E-Journal Program
Pascasarjana Universitas Pendidikan Ganesha. 3, 1-7.

Setyosari, P. 2015. Metode Penelitian Pendidikan dan Pengembangan. Jakarta: Prenada Media Group.

Silaban. 2014. Hubungan Antara Penguasaan Konsep Dan Kreativitas Dengan Kemampuan Memecahkan Masalah Pada Materi Pokok Listrik Statis. Jurnal Penelitian Bidang Pendidikan. 20(1), 65-75.

Suranti, N.M.Y., Gunawan, \& Sahidu, H. 2016. Pengaruh Model Project Based Learning Berbantuan Media Virtual Terhadap Penguasaan Konsep Peserta Didik pada Materi Alat-alat Optik. Jurnal Pendidikan Fisika dan Teknologi. 2(2), 73-79.

Susilawati, Susilawati \& Sridana, N. 2015. Pengaruh Model Pembelajaran Inkuiri Terbimbing Terhadap Keterampilan Proses Sains Siswa. Jurnal Tadris IPA Biologi FITK IAIN Mataram. 3(1), 2336.

Trianto. 2007. Model-model Pembelajaran Inovatif Berorientasi Konstruktivistik. Jakarta: Perpustakaan Nasional.

Wulanningsih, S., Prayitno, B.A., \& Probosar, R.M. 2012. Pengaruh Model Pembelajaran Inkuiri Terbimbing TerhadapKeterampilan Proses Sains Ditinjau dari Kemampuan Akademik Siswa SMA Negeri 5 Surakarta. Jurnal Pendidikan Biologi. 4(2), 3343.

Yeritia, S., Wahyudi \& Rahayu, S. 2017. Pengaruh model pembelajaran inkuiri terbimbing terhadap penguasaan konsep dan kemampuan berpikir kritis fisika peserta didik kelas X SMAN 1 Kuripan tahun ajaran 2017/2018. Jurnal Pendidikan Fisika dan Teknologi. 3(2), 181-187.

Yulianci, S. 2017. Model Inkuiri Terbimbing Berbantuan Multimedia Interaktif Untuk Meningkatkan Penguasaan Konsep Fisika Peserta Didik. Jurnal Pendidikan Fisika dan Teknologi. 3(2), 146-154. 